\title{
24. PRELIMINARY ORGANIC GEOCHEMICAL ANALYSES; SITE 391, LEG 44 OF THE DEEP SEA DRILLING PROJECT
}

\author{
J.N. Cardoso, A.M.K. Wardroper, C.D. Watts, P.J. Barnes, J.R. Maxwell, and G. Eglinton, \\ Organic Geochemistry Unit, School of Chemistry, University of Bristol, Bristol, England \\ and \\ D.G. Mound and G.C. Speers, British Petroleum Exploration and Production Research Division, \\ British Petroleum Research Centre, Sunbury-on-Thames, England
}

\section{INTRODUCTION}

Core samples were studied from Site 391 in the Blake-Bahama Basin $\left(28^{\circ} 13.7^{\prime} \mathrm{N}, 75^{\circ} 36.9^{\prime} \mathrm{W}\right)$. This is the first hole to sample the deep part of the basin and provides a sequence of sediments from Holocene to Jurassic with borehole temperatures from $2^{\circ}$ to $37^{\circ} \mathrm{C}$. The samples, from Holes 391A and 391C (Table 1), range from middle Miocene to lower Tithonian and were examined to determine the source, extent of diagenesis, and petroleum potential of the organic matter. Routine geochemical parameters (e.g., vitrinite reflectance, visual kerogen) were measured and considered in conjunction with more detailed analyses (gas-chromatography and gas chromatography-mass spectrometry [GC and GC-MS]) of hydrocarbons, carboxylic acids, hydroxyacids, and carotenoid pigments.

\section{EXPERIMENTAL PROCEDURES}

Samples were kept frozen in sealed plastic bags prior to examination. Portions were taken from the end of each core sample and prepared by standard techniques (treatment with $\mathrm{HCl} / \mathrm{HF}$ under non-oxidizing conditions) for visual kerogen, sedimentologic, and vitrinite reflectance measurements (Murchison, 1963). Sections of each core were extracted (methylene chloride), decarbonated $(10 \% \mathrm{HCl})$, dried, and then reground to $<100$ mesh for pyrolysis ratio $(\mathrm{CR} / \mathrm{CT})$ and total organic carbon (TOC) determinations by standard methods (Gransch and Eisma, 1967). Following freeze-drying, the bulk of each sample was extracted (methylene chloride) to obtain the hydrocarbons. The extract yielded saturate $(\mathrm{N}+\mathrm{P})$, aromatic $(A+H)$, and residue fractions on column chromatography $\left(\mathrm{SiO}_{2} \mathrm{Gel}\right)$. For general class analysis extractable organic matter was obtained by sonication with propan-2-ol/ $n$-hexane (4/1). The neutral and acid fractions were obtained by partition between ether and water after saponification ( $6 \%$ aq. $\mathrm{KOH})$. Details of the extraction and isolation procedures for the different compound classes have been reported previously (Brooks et al., 1976; Cardoso et al., in press; Watts et al., in press).

The $n$-alkane analyses were performed by gas chromatography (GLC) on a Perkin-Elmer F-17 equipped with a SCOT glass column (OV-101; $50 \mathrm{~m} \times$ $0.5 \mathrm{~mm}$ i.d.). All other analyses were carried out on a Perkin-Elmer F-17 equipped with a WCOT glass
TABLE 1

Sediment Data, Site 391

\begin{tabular}{|c|c|c|}
\hline $\begin{array}{c}\text { Sample } \\
\text { (Interval in } \mathrm{cm} \text { ) }\end{array}$ & $\begin{array}{c}\text { Mean Depth (ss) } \\
\text { (m) }\end{array}$ & Time/Rock \\
\hline $391 \mathrm{~A}-4-3,0-20$ & 205.6 & Middle Miocene \\
\hline $391 \mathrm{~A}-10-0,0-40$ (a) & 373.5 & Middle Miocene \\
\hline $391 \mathrm{~A}-10-0,0-40(\mathrm{~b})$ & 373.5 & Middle Miocene \\
\hline $391 \mathrm{~A}-13-0,0-35$ & 525.5 & Lower Miocene \\
\hline $391 \mathrm{~A}-20-2,0-13$ & 641.1 & Lower Miocene \\
\hline $391 \mathrm{~A}-6-3,0-60$ (a) & 690.3 & Upper Cretaceous \\
\hline $391 \mathrm{~A}-6-3,0-60(\mathrm{~b})$ & 690.3 & Upper Cretaceous \\
\hline $391 \mathrm{~A}-6-3,60-100$ & 690.8 & Upper Cretaceous \\
\hline $391 \mathrm{C}-6-3,120-150$ & 691.4 & Upper Cretaceous \\
\hline $391 \mathrm{C}-7-2,110-125(\mathrm{a})$ & 727.7 & Upper Cretaceous \\
\hline $391 \mathrm{C}-7-2,110-125(\mathrm{~b})$ & 727.7 & Upper Cretaceous \\
\hline $391 C-9-3,92-150$ & 833.7 & Upper Aptian/Lower Albian \\
\hline $391 \mathrm{C}-10-3,110-138$ & 900.8 & Upper Aptian/Lower Albian \\
\hline $391 \mathrm{C}-12-4,68-90$ & 958.3 & Aptian \\
\hline $391 C-16-1,140-150$ & 1021.0 & Upper Valanginian/Lower Barremian \\
\hline $391 \mathrm{C}-26-3,135-144$ & 1147.4 & Upper Berriasian/Lower Valanginian \\
\hline $391 \mathrm{C}-35-4,20-30$ & 1233.3 & Upper Tithonian/Lower Berriasian \\
\hline $391 C-48-2,146-150$ & 1355.0 & Lower Tithonian \\
\hline
\end{tabular}

capillary column (OV-101; $20 \mathrm{~m} \times 0.25 \mathrm{~mm})$. For computerized GC-MS studies, the isolated lipids were chromatographed on a SCOT column (SE-30; $50 \mathrm{~m} \times$ $0.5 \mathrm{~mm}$ i.d.). Spectra were obtained using a Varian Aerograph 1200 chromatograph coupled by a WatsonBiemann separator to a Varian MAT $\mathrm{CH}-7$ single focusing instrument (unless otherwise stated). Automatic data acquistion was made by a PDP-8e computer via interface (Instem Ltd.). Low resolution probe mass spectra were obtained from a Varian MAT $\mathrm{CH}-7$ spectrometer with data acquisition as above. Operating conditions were : ion source temperature $160^{\circ} \mathrm{C}$, electron energy $70 \mathrm{eV}$, and filament current $100 \mu \mathrm{A}$. Samples were introduced by means of a direct-insertion probe.

\section{RESULTS AND DISCUSSION}

Core samples were specifically chosen for organic geochemistry studies and were frozen immediately after collection. Consequently they are not described in the Site 391 Report (this volume). Lithological descriptions completed after the cruise are shown in Tables 2 and 3. The clay minerals did not vary significantly with depth (Table 4). High relative abundances of higher plant debris in the kerogen (Table 5) of some samples (e.g., $391 \mathrm{~A}-4-3$, 0-20 cm; 391C-6-3d, 120-150 cm; 391C-9-3, $92-150 \mathrm{~cm}$ ) indicate a large contribution of terrigenous organic matter to these samples.

The degree of organic diagenesis (DOD) corresponds to $1.0-1.5$ on the Correia scale (Correia and Peniguel, 
TABLE 2

Lithological Description, Hole 391A

\begin{tabular}{|c|c|c|}
\hline $\begin{array}{c}\text { Sample } \\
\text { (Interval in } \mathrm{cm} \text { ) }\end{array}$ & $\begin{array}{l}\text { Sediment } \\
\text { Type }\end{array}$ & Description \\
\hline $4-3,0-20$ & Limestone & $\begin{array}{l}\text { Slightly argillaceous, mudstone, off white light } \\
\text { gray, soft, homogeneous }\end{array}$ \\
\hline $10-0,0-40$ (a) & Limestone & $\begin{array}{l}\text { Slightly argillaceous, mudstone texture, } \\
\text { off white to light gray, occasional pellets of } \\
\text { glauconite, some pale medium gray mudstone } \\
\text { clasts; finely comminuted plant debris }\end{array}$ \\
\hline $10-0,0-40$ (b) & Limestone & $\begin{array}{l}\text { Slighty argillaceous, mudstone texture, } \\
\text { off white to light gray, many medium-pale gray } \\
\text { mudstone fragments up to } 1.5 \mathrm{~mm} \text { long; fine } \\
\text { spicules present; soft }\end{array}$ \\
\hline $13-0,0-35$ & Clay & $\begin{array}{l}\text { Pale gray, non-calcareous, finely laminated, } \\
\text { well consolidated }\end{array}$ \\
\hline $20-2,0-13$ & Clay & $\begin{array}{l}\text { Gray-brown, strongly calcareous, soft, } \\
\text { homogeneous }\end{array}$ \\
\hline
\end{tabular}

TABLE 3

Lithological Description, Hole 391C

\begin{tabular}{|c|c|c|}
\hline $\begin{array}{c}\text { Sample } \\
\text { (Interval in } \mathrm{cm} \text { ) }\end{array}$ & $\begin{array}{l}\text { Sediment } \\
\text { Type }\end{array}$ & Description \\
\hline $6-3,0-60$ (a) & Clay & $\begin{array}{l}\text { Very slightly silty, red-brown grading into green } \\
\text { patches, finely laminated, finely micaceous, } \\
\text { slightly calcareous }\end{array}$ \\
\hline $6-3,0-60(b)$ & Clay & $\begin{array}{l}\text { Slightly silty, dark brown, finely laminated, } \\
\text { white finely micaceous silty partings, very } \\
\text { slightly calcareous, soft }\end{array}$ \\
\hline $6-3,60-100$ & Clay & $\begin{array}{l}\text { Red-brown, finely laminated, very slightly } \\
\text { calcareous, soft }\end{array}$ \\
\hline $6-3,120-150$ & Clay & $\begin{array}{l}\text { Dark gray-black, waxy appearance, non calcareous; } \\
\text { occasional very fine partings of pale gray slightly } \\
\text { silty, very slightly calcareous mudstone, picking } \\
\text { out fine laminations, soft }\end{array}$ \\
\hline $7-2,110-125(a)$ & Clay & $\begin{array}{l}\text { Dark gray-black, very finely micaceous, paper-thin } \\
\text { laminations; very thin white micaceous silty } \\
\text { partings picking out laminations; non-calcareous, } \\
\text { soft }\end{array}$ \\
\hline $7-2,110-125(b)$ & Clay & As above \\
\hline $9-3,92-150$ & Clay & Slightly silty, black, soft; poor sample \\
\hline $10-3,118-138$ & Clay & $\begin{array}{l}\text { Medium gray, very finely micaceous, laminated, } \\
\text { hard very strongly calcareous; finely comminuted } \\
\text { plant debris present }\end{array}$ \\
\hline $12-4,68-90$ & Clay & $\begin{array}{l}\text { Medium gray, calcareous; poor sample - a small } \\
\text { amount unconsolidated ("fluid") mud }\end{array}$ \\
\hline $16-1,140-150$ & Limestone & $\begin{array}{l}\text { Slightly argillaceous, off white to light gray } \\
\text { mudstone texture, pyritic, shell fragments, finely } \\
\text { laminated, well consolidated }\end{array}$ \\
\hline $26-3,135-144$ & Limestone & $\begin{array}{l}\text { Slightly argillaceous, off white to light gray, } \\
\text { mudstone texture, finely micaceous, a little pyrite, } \\
\text { finely laminated, well consolidated }\end{array}$ \\
\hline $35-4,20-30$ & Limestone & $\begin{array}{l}\text { Slightly argillaceous, off white to light gray, } \\
\text { mudstone texture }\end{array}$ \\
\hline $48-2,146-150$ & Limestone & $\begin{array}{l}\text { Argillaceous, pale gray grading to pale brown, } \\
\text { mudstone texture }\end{array}$ \\
\hline
\end{tabular}

TABLE 4

Clay Minerals, Site $391^{\text {a }}$

\begin{tabular}{lcccc}
\hline $\begin{array}{c}\text { Sample } \\
\text { (Interval in cm) }\end{array}$ & Montmorillonite & Illite & Kaolinite & Chlorite $^{\mathrm{b}}$ \\
\hline 391A-13-0, 0-35 & 77.0 & 15.0 & & 8.0 \\
391C-6-3, 120-150 & 32.0 & 39.0 & 13.5 & 14.5 \\
391C-10-3, 110-138 & 28.0 & 56.0 & 7.8 & 8.2 \\
391 C-48-2, 146-150 & 56.0 & 36.0 & 4.0 & 4.0 \\
\hline
\end{tabular}

a Percentage of total argillaceous content determined by X-ray diffraction. bSamples treated with cold dilute $\mathrm{HCl}$ to remove carbonates; this process may have removed some of the chlorite.
1975). Although the DOD increases slightly with depth, it is consistent with that of a very immature sediment. Vitrinite reflectance measurements confirmed the immaturity of the autochthonous component and demonstrated the presence of two types of allochthonous material of higher rank (Tables 6 and 7). We obtained a depth of 1600 meters for the hydrocarbon generation threshold by extrapolating the curve of $\log$ vitrinite reflectivity versus depth for Hole 391C (Figure 1). Samples from Hole 391A had a high carbonate content, very low pyrolysis ratio (CR/CT), low total organic carbon (TOC), and a low total soluble extract (TSE), which was reflected in the low TSE/TOC ratio (Table 8). The concentration of alkanes (SAC) was extremely low and is again reflected in the low $\mathrm{SAC} / \mathrm{TOC}$ ratio. These results confirm the immaturity of the sediments and the lack of significant generation of additional hydrocarbons. The CR/CT ratios, TOC values, and TSE/TOC ratios for Hole 391C samples were mostly low and only Sample 391C-26-3, 135-144 $\mathrm{cm}$ with a carbon preference index (CPI) of 1.02, approaches a mature value (Table 9).

Preliminary investigations of lipid classes isolated from three samples also demonstrated the immaturity and high terrigenous content of the sediments (Table 10). The major triterpanes were $17 \alpha \mathrm{H}$ - and $17 \beta \mathrm{H}$ homohopane (1) with the $17 \beta \mathrm{H}$ isomer predominating as previously reported for immature sediments (Ensminger et al., in press; Van Dorsselaer et al., in press). Hop-17(21)-ene (2) was detected in Samples $391 \mathrm{~A}-13-0,0-35 \mathrm{~cm}$ and $391 \mathrm{C}-12-4,68-90 \mathrm{~cm}$. Mono$\left(\mathrm{C}_{27}-\mathrm{C}_{29}\right)$, di $\left(\mathrm{C}_{28}-\mathrm{C}_{29}\right)$, and tri-unsaturated $\left(\mathrm{C}_{28}-\mathrm{C}_{29}\right)$ sterenes were present in all three samples; cholest-5-ene (3) occurred in 391A-13-0. A number of these compounds have been reported in samples from other DSDP sites (e.g., Cariaco Trench; Simoneit, 1976).

The distribution patterns of the $n$-alkanoic acids of Samples 391C-6-3, 120-150 cm and 391C-12-4, 68-90 $\mathrm{cm}$ showed a significant terrigenous content with strong even to odd predominance (Figures $2 \mathrm{a}$ and $2 \mathrm{~b}$ ). The distribution in the range $n-\mathrm{C}_{14}$ to $n-\mathrm{C}_{20}$ with maximum at $n-\mathrm{C}_{16}$ suggested they had a microbial origin probably characteristic of a marine environment. The terrigenous contribution was greater in 391C-6-3, $120-150 \mathrm{~cm}$ which is consistent with the visual kerogen examination (Table 5).

Concentrations of unsaturated $\mathrm{C}_{18}$ acids (oleic and linoleic acids not separated on the non-polar GC phase used) are low in all three samples (Table 10). The ratio $\mathrm{C}_{18}$ unsaturated $/ \mathrm{C}_{18}$ saturated also decreased downhole from 0.03 to 0.003 in Samples 391C-6-3, 120-150 cm and $391 \mathrm{C}-12-4,68-90 \mathrm{~cm}$. Unsaturated fatty acids are normally subject to rapid diagenesis (e.g., Rhead et al., 1971) in sediments, and if no contamination of the samples during drilling or storage occurred, the presence of these components is an unusual example of their preservation over geological time.

Amounts of branched and cyclic acids were insufficient for analysis by GC-MS. We tentatively established the presence of iso- and anteiso- $\mathrm{C}_{15}$ acids as the most abundant low molecular weight acids, however, on the basis of appropriate GC retention times. Because of the small amounts of hydroxyacids 
TABLE 5

Visual Kerogen Examinations, Site 391

$391 \mathrm{~A}-4-3,0-20 \mathrm{~cm}$

Palynomorphs (dinoflagellate cysts and bisaccate pollen with foraminifer shell linings), well preserved, colorless to pale yellow, DOD 1 .

$50 \%$

Cuticle, well preserved, pale yellow-green to pale yellow-brown.

Wood fragments, unstructured, black and dark brown. (percentages very approximate)

No amorphous organic material was observed.

$391 \mathrm{~A}-10-0,0-40 \mathrm{~cm}$

Sapropel, granular, aggregated, pale yellow-brown, in some cases showing intermediate stages in the breakdown of morphological fragments of plant tissue.

Palynomorphs (dinoflagellates, bisaccate pollen), well preserved, colorless to pale yellow, DOD 1 .

Cuticle and black wood fragments, rare.

391A-13-0, 0-35 cm

Sapropel, granular, aggregated and dispersed, pale yellow brown; some "clumps" exhibit "ghost" plant structures.

Palynomorphs (dinoflagellate cysts and bisaccate pollen), colorless to pale yellow, DOD 1.

Wood fragments, small, black, unstructured, and cuticle are present.

391 A-20-2, 0-13 cm

Sapropel, granular, aggregated and dispersed, pale yellow-brown; some "clumps" exhibit "ghost" plant structures.

Palynomorphs (dinoflagellate cysts and bisaccate pollen), colorless to pale yellow, DOD 1.

Wood fragments, brown, structured and unstructured, rare.

$391 \mathrm{C}-6-3,0-60 \mathrm{~cm}(\mathrm{a}, \mathrm{b})$

This sample yielded both amorphous organic matter and finely comminuted plant fragments; much of the preparation, however, appears to be a mixture of finely comminuted organic and inorganic debris, and a product of faulty preparation technique. No aggregated sapropelic matter was observed. Dinoflagellate cysts, colorless to pale yellow, DOD 1, rare.

Wood fragments, black, unstructured, rare.

$391 \mathrm{C}-6-3,60-100 \mathrm{~cm}$

This sample is almost devoid of organic matter. Only a very small quantity of finely comminuted plant debris and a little aggregated granular sapropel was observed, together with a few dinoflagellate cysts, DOD 1 .

$391 C-6-3,120-150 \mathrm{~cm}$

Sapropel, granular, dispersed, pale.

Small plant fragments (most particles $<30 \mu \mathrm{m}$ ) structured and unstructured, brown and black.

Wood fragments, large, black, unstructured, rare.

Palynomorphs (dinoflagellate cysts), colorless to pale yellow, DOD 1, rare.

$391 \mathrm{C}-7-2,110-125 \mathrm{~cm}$

Sapropel, granular, aggregated and dispersed, brown.

Small plant fragments (most particles $<30 \mu \mathrm{m}$ ) structured and unstructured, brown and black.
TABLE 5 - Continued

Wood fragments, large, black, unstructured, rare.

Palynomorphs (dinoflagellate cysts, bisaccate pollen, spores), yellow, DOD 1.

$391 \mathrm{C}-9-3,92-150 \mathrm{~cm}$

Sapropel, granular, aggregated and dispersed (aggregations contain discrete, brown, spherical globules).

Wood fragments/plant cellular tissue, mostly small particles $<40 \mu \mathrm{m}$, together with some large, mainly black unstructured fragments.

$50 \%$

Palynomorphs (dinoflagellate cyst, bisaccate pollen, spores) DOD 1.

391C-10-3, 110-138 cm

Sapropel, granular, dispersed and aggregated, pale.

Wood fragments/lignified plant tissue, variable size (but mainly small particles $<30 \mu \mathrm{m}$ ), dark brown to black.

Palynomorphs (bisaccate pollen, spores, dinoflagellate cysts), DOD $1(-1.5)$.

\section{$391 \mathrm{C}-12-4,68-90 \mathrm{~cm}$}

Sapropel, granular, largely aggregated (with frequent discrete spherical globules), brown.

Wood fragments/lignified plant tissue, mostly small particles plus some larger fragments of black unstructured wood.

Palynomorphs (pollen, spores, dinoflagellate cysts), rare, DOD 1 - (1.5).

$391 \mathrm{C}-16-1,140-150 \mathrm{~cm}$

Sapropel, granular, largely dispersed.

$60 \%$

Wood fragments/lignified plant tissue, mostly small particles plus some larger fragments of black unstructured wood.

Palynomorphs (dinoflagellate cysts, pollen, spores) pale yellow to pale yellow-brown. DOD 1/1.5.

$391 \mathrm{C}-35-4,20-30 \mathrm{~cm}$

No definite amorphous organic matter is present in either sample. Both contain small fragments wood/lignified plant tissue plus some larger mainly unstructured black fragments. Palynomorph (dinoflagellate cysts, pollen, spores) pale yellow to pale yellow-brown, DOD $1 / 1.5$.

$391 \mathrm{C}-48-2,146-150 \mathrm{~cm}$

Virtually devoid of organic debris.

No palynomorphs observed.

recovered, we could not characterize their components. Demineralization ( $\mathrm{HCl} / \mathrm{HF}$ ) of the extracted 391A-130 sediment yielded a small residue which was analyzed for the presence of bound/polymeric hydroxyacids. Although only a small absolute amount was recovered (about $1 \mathrm{mg}$ ), the fraction represented about $33 \mathrm{ppm}$ of the total organic carbon. The analysis yielded di- and tri-hydroxyacids as the major fraction in Sample 391A$13-0,0-35 \mathrm{~cm}$. Small amounts of a fraction corresponding in $R_{\mathrm{f}}$ value to mono- and dibasic acids (as the methyl esters) were also present; GC analysis of the fraction corresponding to monohydroxyacids, however, showed no measurable quantities of material. Only the di- and tri-hydroxyacid fraction was 
TABLE 6

Vitrinite Reflectance Measurements, Hole 391A

\begin{tabular}{|c|c|c|c|}
\hline \multirow{2}{*}{$\begin{array}{c}\text { Sample } \\
\text { (Interval in } \mathrm{cm} \text { ) }\end{array}$} & \multirow{2}{*}{$\begin{array}{l}\text { Mean } \\
\text { Depth } \\
\text { (m) }\end{array}$} & \multicolumn{2}{|c|}{ Mean Reflectivity ${ }^{a}$} \\
\hline & & Autochthonous & Allochthonous \\
\hline $4-3,0-20$ & 205.6 & 0.23 & 0.63 \\
\hline $4-3,0-20$ & 205.6 & 0.27 & 0.72 \\
\hline $10-0,0-40$ (a) & 373.5 & 0.26 & \\
\hline $10-0,0-40$ (a) & 373.5 & 0.29 & 0.82 \\
\hline $10-0,0-40(b)$ & 373.5 & 0.21 & 0.45 \\
\hline $10-0,0-40(b)$ & 373.5 & 0.27 & 0.50 \\
\hline $13-0,0=35$ & 525.5 & $(0.15)$ & 0.63 \\
\hline $13-0,0=35$ & 525.5 & $(0.11)$ & 0.73 \\
\hline $20-2,0-13$ & 641.1 & 0.30 & \\
\hline $20-2,0-13$ & 641.1 & 0.30 & \\
\hline
\end{tabular}

${ }^{a}$ Columns show recognizably different particle types.

TABLE 7

Vitrinite Reflectance Measurements, Hole 391C

\begin{tabular}{|c|c|c|c|c|c|}
\hline \multirow{2}{*}{$\begin{array}{c}\text { Sample } \\
\text { (Interval in } \mathrm{cm} \text { ) }\end{array}$} & \multirow{2}{*}{$\begin{array}{l}\text { Mean } \\
\text { Depth } \\
(\mathrm{m})\end{array}$} & \multicolumn{4}{|c|}{ Mean Reflectivity ${ }^{a}$} \\
\hline & & Autoch & thonous & Alloch & honous \\
\hline $391 C-6-3,0-60(a)$ & 690.3 & & 0.13 & & 0.88 \\
\hline $391 \mathrm{C}-6-3,0-60$ (a) & 690.3 & & 0.12 & 0.54 & 0.83 \\
\hline $391 \mathrm{C}-6-3,0-60$ (b) & 690.3 & & & & 0.77 \\
\hline $391 \mathrm{c}-6-3,0-60(\mathrm{~b})$ & 690.3 & & 0.14 & & 0.89 \\
\hline $391 \mathrm{C}-6-3,60-100$ & 690.8 & & & & 0.87 \\
\hline $391 C-6-3,60-100$ & 690.8 & & & & 0.93 \\
\hline $391 \mathrm{C}-6-3,120-150$ & 691.4 & & 0.20 & & 0.81 \\
\hline $391 C-6-3,120-150$ & 691.4 & $(0.15)$ & 0.33 & 0.59 & \\
\hline $391 \mathrm{C}-7-2,110-125(\mathrm{a})$ & 727.7 & $(0.14)$ & & 0.55 & \\
\hline $391 C-7-2,110-125(a)$ & 727.7 & & 0.25 & 0.45 & \\
\hline $391 \mathrm{C}-7-2,110-125$ (b) & 727.7 & & 0.29 & & \\
\hline $391 \mathrm{c}-7-2,110-125$ (b) & 727.7 & $(0.14)$ & & & 0.87 \\
\hline $391 C-9-3,92-150$ & 833.7 & & 0.26 & & \\
\hline $391 C-9-3,92-150$ & 833.7 & & 0.31 & 0.49 & \\
\hline $391 \mathrm{C}-10-3,110-138$ & 900.8 & $(0.10)$ & 0.32 & & \\
\hline $391 \mathrm{C}-10-3,110-138$ & 900.8 & $(0.12)$ & 0.28 & & \\
\hline $391 C-12-4,68-90$ & 958.3 & $(0.09)$ & 0.28 & & \\
\hline $391 C-12-4,68-90$ & 958.3 & & 0.24 & & \\
\hline $391 \mathrm{C}-16-1,140-150$ & 1021 & $(0.09)$ & 0.26 & 0.55 & \\
\hline $391 \mathrm{C}-16-1,140-150$ & 1021 & & 0.33 & 0.59 & \\
\hline $391 C-26-3,135-144$ & 1147.4 & & 0.19 & 0.49 & \\
\hline $391 \mathrm{C}-26-3,135-144$ & 1147.4 & & 0.32 & 0.61 & \\
\hline $391 \mathrm{C}-35-4,20-30$ & 1233.3 & & 0.36 & & 0.89 \\
\hline $391 C-35-4,20-30$ & 1233.3 & & & & 0.91 \\
\hline $391 \mathrm{C}-48-2,146-150$ & 1355 & & & & 1.00 \\
\hline $391 \mathrm{C}-48-2,146-150$ & 1355 & & & & 0.93 \\
\hline
\end{tabular}

${ }^{\mathrm{a} C}$ Columns show recognizably different particle types.

characterized further by GC-MS. The distribution (as methyl esters, TMSi ethers) is shown in Figure 3. Assignments were based on mass spectral interpretation alone, except for the component characterized as a mixture of 9,16- and $10,16-\mathrm{diOHC}_{16}$, which was co-injected with a standard, naturally occurring, mixture isolated from a plant cutin (Agave). Hydroxyacids in sediments are thought to derive principally from microbes (bacteria, yeasts) and from higher plants (e.g., Cardoso et al., in press). In the case of higher plants, they occur either as soluble constituents in the plant epicuticular wax or, crossesterified, in the polymers cutin and suberin which form the external cover of the aerial parts of the plants. Monohydroxyacids $\left(\alpha-, \beta-, \omega^{-}\right.$, and $\left.\omega^{-1}\right)$ are produced

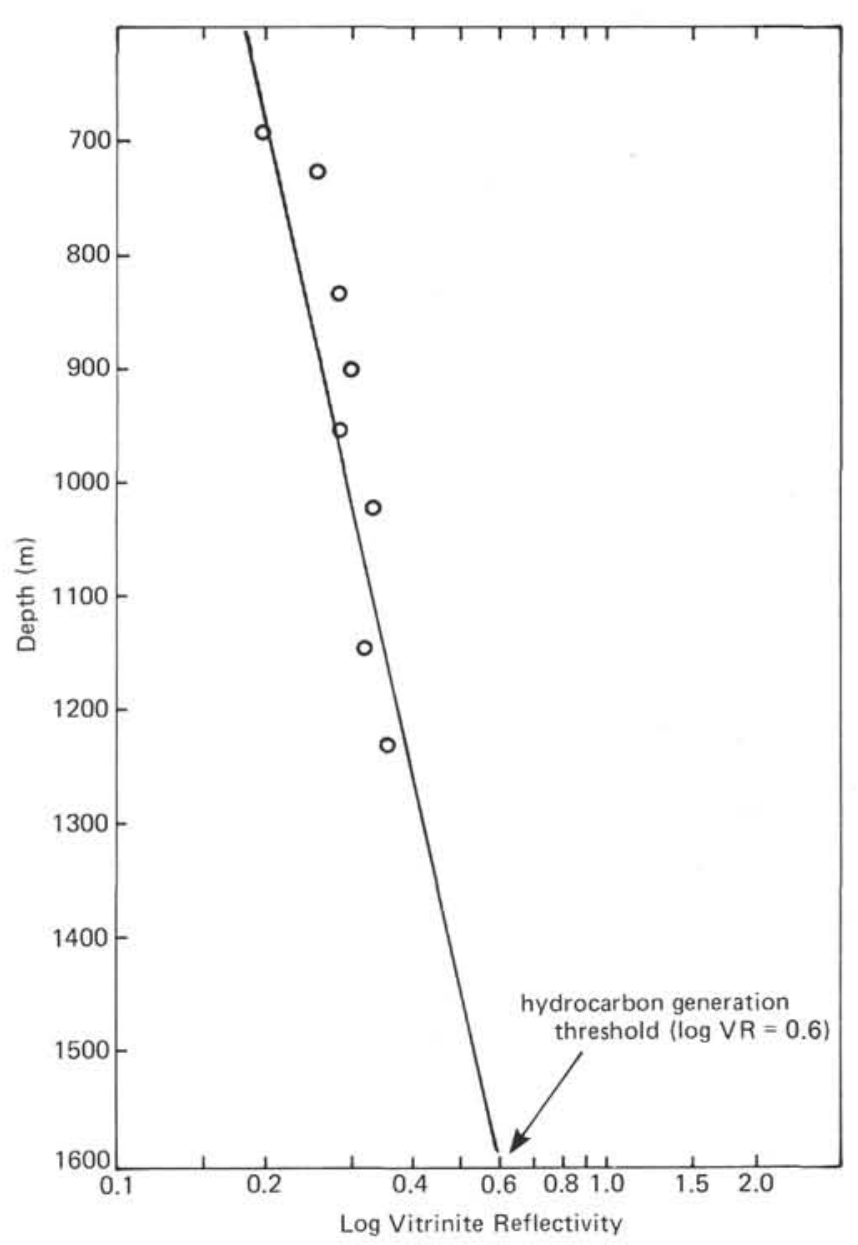

Figure 1. Increase in vitrinite reflectivity with depth for sediment sample from Hole 391C. Extrapolation of the curve indicates that the hydrocarbon generation threshold would be reached at about 1600 meters depth. Where only single vitrinite reflectance values were available in Table 7 these were used in plotting the graph; for more than one value the averages were plotted. When the distribution suggested lower reflectivity the largest of the values was used.

TABLE 8

Source Rock Data, Hole 391A

\begin{tabular}{cccccccc}
\hline $\begin{array}{c}\text { Sample } \\
\text { (Interval in cm) }\end{array}$ & $\begin{array}{c}\mathrm{CO}_{3} \\
(\% \mathrm{wt})\end{array}$ & $\mathrm{CR}^{\mathrm{C}} \mathrm{CT}^{\mathrm{a}}$ & $\begin{array}{c}\mathrm{TOC}^{\mathrm{b}} \\
(\% \mathrm{wt})\end{array}$ & $\begin{array}{c}\mathrm{TSE}^{\mathrm{c}} \\
(\% \mathrm{wt})\end{array}$ & $\begin{array}{c}\frac{\mathrm{TSE}}{\mathrm{TOC}} \\
(\%)\end{array}$ & $\begin{array}{c}\mathrm{N}+\mathrm{P} \\
(\% \mathrm{TSE})\end{array}$ & $\begin{array}{c}\frac{\mathrm{SAC}^{\mathrm{T}}}{\mathrm{TOC}} \\
(\%)\end{array}$ \\
\hline $4-3,0-20$ & 90.6 & 0.22 & 0.15 & 0.0046 & 3.07 & 6.34 & 0.19 \\
$10-0,0-40$ & 78.3 & 0.14 & 0.25 & 0.0091 & 3.64 & 6.34 & 0.23 \\
$10-0,0-40$ & 80.9 & 0.12 & 0.19 & 0.0090 & 4.74 & 3.17 & 0.15 \\
$13-0,0-35$ & 54.3 & 0.27 & 1.06 & 0.0282 & 2.66 & 1.21 & 0.03 \\
$20-2,0-13$ & 15.6 & 0.22 & 0.77 & 0.0142 & 1.84 & 4.66 & 0.09 \\
\hline
\end{tabular}

${ }^{\mathrm{a}} \mathrm{CR} / \mathrm{CT}=$ pyrolysis ratio (Gransch and Eisma, 1967).

botal organic carbon.

Total soluble extract.

d $\mathrm{SAC}=$ saturated alkane concentrate $(\mathrm{N}+\mathrm{P})$.

via general biochemical pathways and provide few clues to their source, but their presence in sediments is probably of microbial origin. $\mathrm{Di}$ - and tri-hydroxyacids are less widely distributed in sediments and their occurrence as abundant constituents appears to be restricted to higher plants (cutin and suberin). The 
TABLE 9

Source Rock Data, Hole 391C

\begin{tabular}{|c|c|c|c|c|c|c|c|c|}
\hline $\begin{array}{c}\text { Sample } \\
\text { (Interval in } \mathrm{cm} \text { ) }\end{array}$ & $\begin{array}{l}\mathrm{CO}_{3} \\
\text { (\% wt) }\end{array}$ & $\mathrm{CR} / \mathrm{CT}$ & $\begin{array}{l}\text { TOCa } \\
(\% \text { wt })\end{array}$ & $\begin{array}{l}\mathrm{TSE}^{\mathrm{b}} \\
(\% \mathrm{wt})\end{array}$ & $\frac{\text { TSE }}{\text { TOC }}$ & $\begin{array}{c}\mathrm{N}+\mathrm{P} \\
(\% \mathrm{TSE})\end{array}$ & $\frac{\mathrm{SAC}^{\mathrm{C}}}{\mathrm{TOC}}$ & $\begin{array}{c}\text { CPI } \\
\mathrm{C}_{20}-\mathrm{C}_{32}\end{array}$ \\
\hline $6-3,0-60$ (a) & 10.6 & 0.12 & 0.26 & 0.0033 & 1.27 & 24.47 & 0.31 & 1.34 \\
\hline $6-3,0-60$ (b) & 5.7 & 0.07 & 0.45 & 0.0061 & 1.36 & 9.42 & 0.13 & 1.49 \\
\hline $6-3,60-100$ & 8.2 & 0.09 & 0.22 & 0.0050 & 2.27 & 5.07 & 0.12 & 1.25 \\
\hline $6-3,20-150$ & 8.5 & 0.06 & 0.45 & 0.0025 & 0.56 & 17.20 & 0.096 & 1.53 \\
\hline $7-2,110-125$ (a) & 7.2 & 0.32 & 1.20 & 0.0079 & 0.66 & 8.48 & 0.056 & 1.79 \\
\hline $7-2,110-125(\mathrm{~b})$ & 13.5 & 0.16 & 0.93 & 0.0106 & 1.14 & 12.01 & 0.014 & 1.58 \\
\hline $9-3,92-150$ & 15.2 & 0.30 & 1.30 & 0.0140 & 1.08 & 9.11 & 0.098 & 1.37 \\
\hline $10-3,110-138$ & 33.2 & 0.49 & 2.06 & 0.0252 & 1.22 & 2.14 & 0.026 & 1.19 \\
\hline $12-4,68-90$ & 11.7 & 0.40 & 1.25 & 0.0138 & 1.10 & 22.33 & 0.25 & 1.79 \\
\hline $16-1,140-150$ & 87.7 & 0.46 & 0.39 & 0.0084 & 2.15 & 8.09 & 0.17 & 1.26 \\
\hline $26-3,135-144$ & 61.7 & 0.09 & 0.20 & 0.0049 & 2.45 & 9.48 & 0.23 & 1.02 \\
\hline $35-4,20-30$ & 77.3 & 0.08 & 0.08 & 0.0037 & 4.63 & 10.99 & 0.51 & 1.20 \\
\hline $48-2,146-150$ & 74.3 & 0.07 & 0.10 & 0.0034 & 3.4 & 21.40 & 0.73 & \\
\hline
\end{tabular}

${ }^{\mathrm{a}}$ Total organic carbon.

$\mathrm{b}_{\text {Total soluble extract. }}$

${ }^{\mathrm{c}} \mathrm{SAC}=$ saturated alkane concentrate $(\mathrm{N}+\mathrm{P})$.

TABLE 10

Abundance of Lipid Classes in Sediment Samples From Site 391

\begin{tabular}{|c|c|c|c|c|c|c|c|}
\hline \multirow{3}{*}{$\begin{array}{c}\text { Sample } \\
\text { (Interval in cm) }\end{array}$} & \multicolumn{7}{|c|}{ Abundances $^{\mathrm{a}}$} \\
\hline & \multicolumn{2}{|c|}{ Hydrocarbons } & \multicolumn{4}{|c|}{ Carboxylic Acids } & \multirow{2}{*}{$\begin{array}{l}\text { carotenoid } \\
\text { pigments }\end{array}$} \\
\hline & $n$-alkanes & branched-cyclic ${ }^{b}$ & $n$-alkanoic & $n$-alkenoic ${ }^{\mathrm{c}, \mathrm{d}}$ & $\mathrm{B} / \mathrm{C}$ alkanoic ${ }^{\mathrm{d}}$ & hydroxyd,e & \\
\hline $391 \mathrm{~A}-13-0,0-35$ & 0.07 & 0.04 & f & f & f & $\mathrm{g}$ & 0.045 \\
\hline $391 C-6-3,0-60$ & 0.11 & 0.18 & 0.02 & 0.0007 & 0.002 & $\mathrm{~g}$ & $\mathrm{f}$ \\
\hline $391 C-12-4,68-90$ & 1.44 & 2.87 & 1.60 & 0.005 & 0.007 & $\mathrm{~g}$ & g \\
\hline
\end{tabular}

${ }^{\mathrm{a}} \mathrm{Ppm}$ values relative to dry wt of sediment; quantitation by measurement of GC peak height, except carotenoids (uv/vis absorption).

$\mathrm{b}_{\text {Alkanes and alkenes. }}$

${ }^{c} \mathrm{C}_{18}$ unsaturated acids.

dQuantitization by GC only; no GC-MS information.

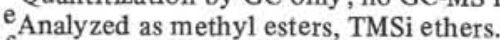

$f_{\text {Absent. }}$

grace amounts which were not further characterized.

occurrence of di-hydroxyacids as the major hydroxyacids in the DSDP samples therefore suggests a higher plant contribution. This is further supported by the presence of 9,16- and 10,16-diOHC 16 acids which are common components of higher plant cuticular membranes. The other constituents of the hydroxyacid fraction are not commonly reported for angiosperm cuticles and probably reflect a contribution from lower plant forms. Unfortunately, because of the paucity of reports on the cutin composition of lower plants and the absence of pollen results for Sample 391A-13-0, 0$35 \mathrm{~cm}$, we cannot definitely identify the contributing plant species. However, the predominance of the 9,16over the 10,16-diOHCis isomer is noteworthy: in angiosperm cuticles the opposite situation generally occurs and one of the few reports (Hunneman and Eglinton, 1972) of a marked predominance of the 9,16isomer refers to a gymnosperm cutin, Pinus sylvestris. It may be worthwhile to investigate whether this distribution of isomers in the DSDP sample does in fact correlate with a contribution from coniferous plants, as appears to be the case with a Black Sea sample (Cardoso, 1976).

A bicyclic aromatic carotene occurs in samples from Hole 391A (0.04 ppm in Sample 391A-13-0, 0-35 cm). Comparison of the mass and electronic spectra, and thin-layer chromatographic mobility with those of renieratene (4) and isorenieratene (5) suggests some structural similarity. This is the oldest sediment from which an intact carotene has been isolated (Watts and Maxwell, in press) and reflects the excellent preservation of organic matter in these core samples. The very low concentrations of other carotenoid pigments in Samples 391A-13-0, 0-35 cm and 391C-12$4,68-90 \mathrm{~cm}$ did not permit characterization.

\section{CONCLUSIONS}

The organic diagenesis and vitrinite reflectance values, the source rock data, and distribution of lipids are all characteristic of immature sediments. Vitrinite 

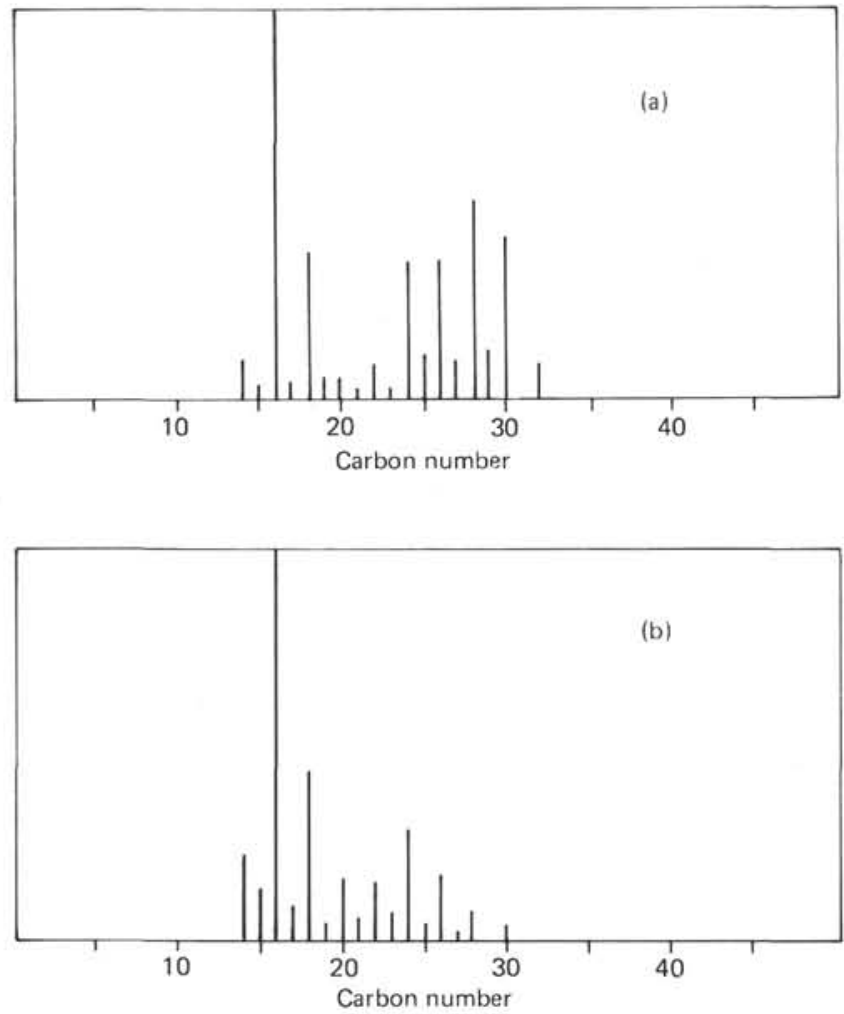

Figure 2. Normalized carbon number distribution of the n-alkanoic acids from sediment Samples (a) 391C-6-3, $120-150 \mathrm{~cm}$ and (b) $391 \mathrm{C}-12-4,68-90 \mathrm{~cm}$.

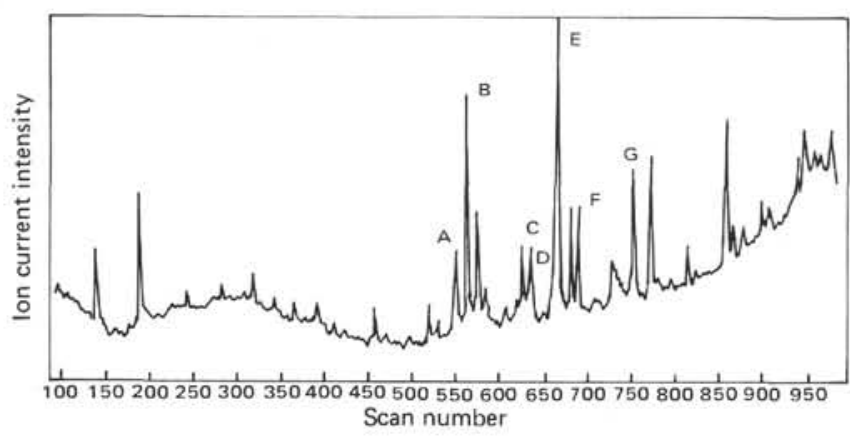

Figure 3. C-GC-MS analysis of the hydroxyacids fraction (after treatment with $\mathrm{HCl} / \mathrm{HF}$ ) from Sample 391A-4-3, $0-20 \mathrm{~cm}$. Peak assignment was as follows: (A) 8,15diOHC $_{15} ;(B)$ mixture of 9,16- and 10,16-diOHC $16 ;(C)$ unknown; (D) 11,18-diOHC 18 en; (E) 11,18-diOHC 18 ; (F) 11,18-diOHC 18 en; (G) unknown.

reflectance data indicate that the hydrocarbon generation threshold occurs at 1600 meters. The presence of higher plant debris in the kerogen, the predominance of bound dihydroxy- over monohydroxyacids in $391 \mathrm{~A}-13-0$ and the isolation of $n$ alkanoic acids in the $n-\mathrm{C}_{20}$ to $n-\mathrm{C}_{30}$ range shows terrigenous contribution of organic matter.

\section{ACKNOWLEDGMENTS}

We thank the Natural Environment Research Council (NERC GR/3/655 and GR/3/2420), the National Aero- nautics and Space Administration (subcontract from NGL 05-003-003), and the Nuffield Foundation for support. AMKW, JNC, and CDW are grateful to the Science Research Council, the British Council, and the Petroleum Research Fund of the American Chemical Society, respectively, for Research Studentships. PJB acknowledges receipt of a Research Assistantship from NERC. DGM and GCS wish to thank the British Petroleum Co. Ltd. for permission to publish this work.

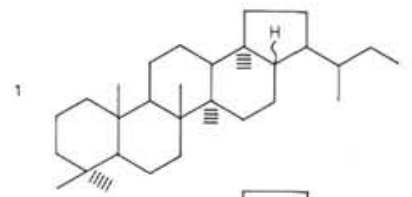<smiles>CC(C)CCCC(C)C1CCC2C3CC=C4CCCCC4(C)C3CCC12C</smiles><smiles>CC(/C=C/C=C(C)/C=C/c1ccc(C)c(C)c1C)=C\C=C\C=C(C)\C=C\C=C(C)\C=C\c1c(C)ccc(C)c1C</smiles><smiles>CC(/C=C/C=C(C)/C=C/c1c(C)ccc(C)c1C)=C\C=C\C=C(C)\C=C\C=C(C)\C=C\c1c(C)ccc(C)c1C</smiles>

\section{REFERENCES}

Brooks, P.W., Eglinton, G., Gaskell, S.J., McHugh, D.J., Maxwell, J.R., and Philp, R.P., 1976. Lipids of Recent sediments, Part I: straight-chain hydrocarbons and carboxylic acids of some temperate lacustrine and subtropical lagoonal/tidal flat sediments: Chem. Geol., v. 18 , p. 21.

Cardoso, J.N., 1976. Ph.D. Thesis, University of Bristol.

Cardoso, J.N., Eglinton, G. and Holloway, P.J., in press. The use of cutin acids in the recognition of higher plant contribution to Recent sediments: In Advances in organic geochemistry 1975.

Correia, M. and Peniguel, L., 1975. Etude microscopique de la matiere organique-ses applications a l'exploration petroliere: Centre Red. PAN-SNPA, Bull., v. 9, p. 99.

Ensminger, A., Albrecht, P., and Ourisson, G., in press. Evolution of polycyclic alkanes under the effect of burial (Early Toarcian shales, Paris Basin): In Advances in organic geochemistry 1975.

Gransch, J.A. and Eisma, E., 1967. Characterisation of the insoluble organic matter of sediments by pyrolysis. In Hobson, G.D. and Speers, G.C. (Eds.), Advances in organic geochemistry, 1966: New York (Pergamon Press), p. 407.

Hunneman, D.H. and Eglinton, G., 1972. Gas chromatographic-mass spectrometric studies of long chain hydroxy acids IV. The constituent acids of gymnosperm cutins: Phytochem., v. 11, p. 1989. 
Murchison, D.G., 1963. Reflectance techniques in coal petrology and their possible application in ore mineralogy: Inst. Mining Metallurgy Trans., v. 73, p. 479.

Rhead, M.M., Eglinton, G., Draffan, G.H., and England, P.J., 1971. Conversion of oleic acid to saturated fatty acids in Severn Estuary sediments: Nature, v. 232, p. 327.

Simoneit, B.R.T., 1976. Sources of organic matter in oceanic sediments: Ph.D. Thesis, University of Bristol.
Watts, C.D. and Maxwell, J.R., in press. Carotenoid diagenesis in a marine sediment: Geochem. Cosmochim. Acta.

Watts, C.D., Maxwell, J.R., and Kjösen, H., in press. The potential of carotenoids as environmental indicators. In Advances in organic geochemistry 1975.

Van Dorsselaer, A., Albrecht, P., and Connan, J., in press. Changes in composition of polycyclic alkanes by thermal maturation (Yallourn lignite, Australia). In Advances in organic geochemistry 1975. 